\title{
PERANAN AKUNTAN DALAM PELAKSANAAN CORPORATE SOCIAL RESPONSIBILITY PADA RUMAH SAKIT DI WILAYAH KABUPATEN SUMENEP
}

\author{
Syahril, SE., M.Ak ${ }^{1}$ \\ Dedy Arfiyanto, SE., MM ${ }^{2}$ \\ ${ }^{1}$ Dosen Program Studi Akuntansi, Universitas Wiraraja \\ syahril49@yahoo.co.id \\ ${ }^{2}$ Dosen Program Studi Manajemen, Universitas Wiraraja \\ mrdego.ar@gmail.com
}

\begin{abstract}
Accountants have a very big role to encourage companies to get involved in activities that show concern for environmental issues Social or Corporate Social Responsibility.

The purpose of this study is to determine the role of accountants, especially internal accountants in the implementation of Corporate Social Responsibility Hospital in the District Sumenep. This research is descriptive research with qualitative approach. By using this qualitative Descriptive research, writer use to describe, interpret and describe data that writer get from observation, interview and documentation. The analysis uses an interactive model with three procedures: Data Reduction, Presentation of Data and Drawing Conclusions.

The role of internal accountants in the implementation of social activities is needed for corporate social responsibility (Hospital in Sumenep District). Because the involvement of internal accountants is very big influence on the decision-making process related to social problems or Corporate Social Responsibility (Corporate Social Responsibility)
\end{abstract}

Keywords : Internal Accountant, Corporate Social Responsibility, Hospital

\section{PENDAHULUAN}

Seiring dengan perkembangan konsep manajemen tersebut, para akuntan juga membicarakan bagaimana permasalahan tanggungjawab sosial ini dapat diadaptasikan dalam ruang lingkup akuntansi (Hines,1988) dalam Maksum, (1991), sehingga tujuan utama pelaporan keuangan guna memberikan informasi kepada para pemegang saham dan kreditur menjadi ikut bergeser pula kearah kecendrungan bahwa perlunya pelaporan yang bersifat dari luar organisasi perusahaan (externality) dalam rangka memberikan informasi kepada beberapa kelompok orang luar yang berkepentingan terhadap perusahaan. Berdasarkan uraian diatas dapat dipahami bahwa ide dasar yang melandasi perlunya dikembangkan akuntansi sosial (social accounting), secara umum adalah tuntutan terhadap perluasan tanggungjawab perusahaan.

Dengan berkembangnya Ilmu Ekonomi sekarang ini dan meningkatnya Kesadaran pengusaha-pengusaha terhadap lingkungan maka perusahaan membutuhkan informasi-informasi tentang lingkungan sosial dan biasanya dalam perusahaan ada suatu bagian yang 
menangani tentang masalah akuntansi yang disebut akuntan intern yang memberikan informasi tentang masalah yang berhubungan dengan perusahaan disini adalah masalah lingkungan sosial. Akuntan Intern mempunyai peranan yang sangat besar untuk mendorong perusahaan supaya ikut terlibat dalam kegiatan yang menunjukkan kepedulian terhadap permasalahan lingkungan Sosial.

Secara spesifik tugas akuntan intern ialah mengidentifikasi, mengukur mengklasifikasikan dan melaporkan informasi yang dapat membantu manajer menjalankan proses perencanaan, pengendalian dan pengembalian keputusan. Perubahan-perubahan yang terjadi pada lingkungan eksternal perusahaan yang berpengaruh pada proses perencanaan, pengendalian dan pengambilan keputusan juga merupakan informasi yang harus disampaikan akuntan intern kepada manajer. Selain itu Menurut Martin (1991), Sebagaimana dikutip oleh Gray et.al. (1993:41) Perusahaan yang serius menanggapi isu-isu lingkungan tidak hanya menempelkan slogan-slogan bebas polusi tetapi juga menginternalisasikan dalam system akuntansi. Sehingga perusahaan mengetahui posisi keuangan setelah menjalankan aktivitas lingkungan.

\section{Corporate Social Responsibility} (CSR) adalah sebuah program yang mengimplementasikan tanggung jawab sosial perusahaan kepada masyarakat luas yaitu pihak stakeholders, dimana tanggung jawab sosial perusahaan ini hendaknya dilingkungan dengan sukarela (Valunteer) oleh perusahaan bukan sebagai kewajiban.

Dalam era globalisasi ini, perusahaan di Indonesia melakukan kegiatan terencana supaya sampai kepada tujuan khusus juga tujuan umum yang telah mereka tentukan. Untuk mencapai tujuan ini, tentu saja melewati banyak macam pelaksanaan kegiatan dimana bukan hanya mengikutsertakan satu pihak saja atau perusahaan itu sendiri, tetapi juga secara langsung atau tidak langsung terkait dengan pihak luar.

Oleh karena itu perusahaan secara keseluruhan yang berasal dari lingkungan pada akhirnya dikonsumsi oleh lingkungan tidak hanya memiliki tanggung jawab ekonomis tapi juga harus melaksanakan kegiatan operasional yang akan berintekrasi secara langsung maupun tidak langsung dengan lingkungan seperti kegiatan Corporate Social Responsibility (CSR) yamg merupakan prinsip dunia usaha untuk terus bertindak etis, berjalan secara legal untuk peningkatan ekonomi, dengan bersamanya peningkatan kualitas hidup masyarakat luas, peningkatan 
kualitas hidup karyawan dan keluarganya. Adanya kepercayaan bahwa keberlangsungan perusahaan akan terjamin apabila perusahaan memperhatikan dimensi terkait lainnya, seperti dimensi pembangunan ekonomi, pembangunan sosial, dan perlindungan lingkungan yang sangat erat hubungannya dalam rangka mencapai pembangunan berkelanjutan.

Dengan demikian tiga (3) dimensi itu disebut konsep Triple Battom Line (3P) yaitu: profit (ekonomi), people (sosial), plannet (lingkungan) yang menjadi dalam satu kesatuan, sehingga pembangunan berkelanjutan dalam pelaksanaan CSR menjadi peranan utama community development (perkembangan masyarakat) berupa pemberdayaan masyarakat kemudian dikembangkan untuk mencapai keberhasilan yang baik di mata para stakeholders (pemangku kepentingan) perusahaan juga menjadi sangat penting seiring dengan perubahan paradigma yang mengatakan bahwa CSR bukan hanya dipandang sebagai sentra biaya (cost Center) tetapi juga sebagai sentra laba (profit center) dimasa yang akan datang. Dari konteks tersebut profitabilitas perusahaan merupakan tantangan perusahaan tersendiri, karena perusahaan juga harus memperhatikan orang dan lingkungan sekitarnya.
Artinya pelaksanaan CSR dalam perusahaaan telah memiliki kedudukan penting. Pertama: pada beberapa perusahaan multinasional, nasional, dan Badan Usaha Milik Negara (BUMN), CSR sudah menjadi departemen/divisi mandiri yang secara struktur organisasi bertanggung jawab langsung kepada direktur. Kedua : regulasi CSR juga semakin berkembang, mulai dari Undang-Undang Perseroan Terbatas (PT), Undang-Undang Penanaman Modal, Keputusan Menteri BUMN, Undang-Undang Usaha Mikro, Kecil dan Menengah, ISO 26000. Dengan dikukuhkannya UU dan peraturan tersebut, maka kedudukan CSR sebagai salah satu kewajiban perusahaan semakin kuat dengan memiliki kedudukan atas peraturan atau dasar hukum.

Rumah sakit yang merupakan lembaga dunia usaha yang berhubungan langsung dengan kepentingan masyarakat, selama ini sudah menjalankan program CSR atau tanggung jawab sosialnya kepada masyarakat. Aktivitas ini dilakukan untuk mendorong menumbuh kembangkan tentang kesehatan pembangunan ekonomi, pembangunan sosial, dan perlindungan lingkungan yang sangat erat hubungannya dalam rangka mencapai pembangunan berkelanjutan. 
FAKULTAS EKONOMI DAN BISNIS UNIVERSITAS WIRARAJA - MADURA

\section{METODOLOGI PENELITIAN}

\section{Jenis Penelitian}

Tujuan dari penelitian ini adalah untuk mendapatkan gambaran yang jelas, secara sistematis tentang "Peran Akuntan Intern dalam pelaksanaan corporate social responsibility pada Rumah Sakit Di Wilayah Kabupaten sumenep". Maka jenis penelitian ini adalah penelitian deskriptif dengan pendekatan kualitatif.

Penelitian deskriptif digunakan untuk menganalisis dan menyajikan data yang bersifat kualitatif. Sedangkan mengenai pendekatan kualitatif yang dikemukakan oleh Bogdan dan Tylor sebagaimana dikutip oleh Moleong (2000:3), adalah "prosedur yang menghasilkan data deskriptif berupa kata-kata tertulis atau lisan dan orangorang dan pelaku yang dapat diamati”.

\section{Jenis dan Sumber data}

Data yang diperoleh adalah data primer. Data primer adalah data yang diperoleh langsung dari responden atau nara sumber. Menurut Bungin (2005:122), data primer adalah data yang langsung diperoleh dari sumber data pertama di lokasi penelitian atau objek penelitian. Dalam penelitian ini, data primer diperoleh dengan cara wawancara langsung dengan Para Informan yaitu Akuntan Intern, Kabag Tata Usaha, Kasubag Keuangan, Kasubbag Umum \& Perencanaan
Beserta Pimpinan di Rumah Sakit yang ada di Wilayah Kabupaten Sumenep,

\section{Metode Pengumpulan Data}

1. Observasi

Metode Observasi menurut

Kartono (1990:157) adalah

"pengumpulan data dengan studi yang disengaja dan sistematis tentang fenomena sosial dan gejalagejala alam dengan jalan pengamatan dan pencatatan". Metode observasi ini, penulis gunakan untuk memperoleh data tentang Peran Akuntan Intern dalam pelaksanaan corporate social responsibility pada Rumah Sakit di wilayah Kabupaten Sumenep.

2. Wawancara

Metode wawancara menurut Kartono (1990:187) "adalah pengumpulan data dengan melalui suatu percakapan, tanya jawab lisan antara dua orang atau lebih yang duduk berhadapan secara fisik dan diarahkan pada suatu permasalahan tertentu". Metode ini penulis gunakan untuk memperoleh data tentang Peran Akuntan Intern dalam pelaksanaan corporate social responsibility pada Rumah Sakit di wilayah Kabupaten Sumenep.

3. Dokumentasi

Dokumen menurut Guba dan Lincoln sebagaimana dikutip oleh Moleong (2000:161), adalah setiap 
bahan tertulis atau film. Jadi dokumentasi merupakan metode pengumpulan data dengan cara mengadakan pencatatan-pencatatan dari arsip yang ada hubungannya dengan permasalahan yang dikaji oleh penulis.

\section{Metode Analisis Data}

Penelitian ini menggunakan metode analisa deskriptif kualitatif dimana metode ini dengan melakukan pencatatan dan pengagendaan informasi dari para informan terpilih, serta mendokumentasikan, kemudian menguraikan data, sehingga diperoleh deskripsi suatu fenomena tentang peranan akuntan dalam pelaksanaan corporate social responsibility pada Rumah Sakit di wilayah Kabupaten Sumenep.

$$
\text { Dalam penelitian ini }
$$
menggunakan analisa data yang telah dikembangkan oleh Mills dan Huberman (1992:15-20) yaitu analisis model interaktif dengan tiga prosedur:

1. Reduksi Data

2. Penyajian data

3. Menarik Kesimpulan

\section{HASIL DAN PEMBAHASAN}

Sesuai dengan tujuan penelitian ini, untuk menjawab pertanyaan penelitian yang berkaitan dengan Peran Akuntan dalam Pelaksanaan Corporate Social Responsibility yang telah dilaksanakan oleh Rumah Sakit diwilayah kabupaten
Sumenep ( Rumah Sakit Dr. H. Moh. Anwar (RSUD) Sumenep, dan Rumah Sakit Islam Garam Kalianget) perlu adanya pemahaman tentang Corporate Social Responsibility (CSR) adalah pertanggungjawaban sosial organisasi/ unit kerja yang profit atau non profit.

Corporate Social Responsibility dalam bahasa Indonesia dikenal dengan tanggungjawab sosial Perusahaan dimaksudkan sebagai upaya Rumah Sakit diwilayah kabupaten Sumenep untuk meningkatkan kepedulian terhadap masalah sosial dan lingkungan dalam kegiatan usaha dan juga pada cara Rumah Sakit berinteraksi dengan stakeholder yang dilakukan secara sukarela. Selain itu, tanggungjawab sosial diartikan pula sebagai komitmen untuk berkontribusi dalam pembangunan ekonomi berkelanjutan, bekerja dengan para karyawan perusahaan, keluarga karyawan dan masyarakat setempat (local) dalam rangka meningkatkan kualitas kehidupan.

Pelaksanaan Corporate Social Responsibility Rumah Sakit di Wilayah Kabupaten Sumenep.

Corporate Social Responsibility di dua Rumah Sakit yang ada di Kabupaten Sumenep dilaksanakan secara langsung oleh organisasi atau unit kerja di bawah divisi humas atau public relations, namun pada Rumah Sakit Dr. H. Moh. Anwar (RSUD) 
Kabupaten Sumenep Program CSR

banyak dikelola/ terkonsentrasi dibagian

Informasi dan Evaluasi yang membentu

Instalasi Peduli Pelanggan (IPP) juga

dikenal dengan sebutan Tempat

Pengaduaan Masyarakat. Sedangkan Di

Rumah Sakit Islam Garam Kalianget

Sumenep dilaksanakan secara langsung

oleh divisi humas atau public relations.

Pada awal perkembangannya,

bentuk Corporate Social Responsibility

yang paling umum adalah pemberian

bantuan terhadap organisasi-organisasi

lokal dan masyarakat miskin.

Kegiatan Corporate Social Responsibility yang dilakukan RSUD Dr. H. Moh. Anwar Sumenep saat ini sudah mulai beragam, disesuaikan dengan kebutuhan masyarakat setempat berdasarkan kebutuhan yang ada seperti :

1. Mulai dari pengolahan limbah $R S$ yang peduli pada lingkungan.

2. Kerja sama dengan beberapa perguruan tinggi.

3. Perlindungan kesehatan bagi karyawan dan pelanggan.

4. Peningkatan SDM karyawan.

5. Pemberian beasiswa.

6. Bantuan bencana kemanusiaan.

7. Pengembangan skema perlindungan sosial berbasis masyarakat.

8. Interaksi atau keterlibatan Rumah Sakit dengan masyarakat.

Hal tersebut diatas terungkap dari wawancara dengan informan Kunci (Bapak Jaka) Pada tanggal 15 November 2016 dan dikompermasi dengan bagian informasi \& Evaluasi Pada tanggal 16 November 2016 yang menyatakan bahwa:
Memang benar kegiatan Corporate Social Responsibility yang dilakukan RSUD Dr. H. Moh. Anwar Sumenep saat ini sudah mulai beragam, disesuaikan dengan kebutuhan masyarakat setempat berdasarkan kebutuhan, Yang rata-rata pengelolaannya melalui bidang Informasi \& Evaluasi yang mempunyai Instalasi Peduli Pelanggan/pengaduan masyarakat.

Pernyataan lebih lanjut

diungkapkan oleh informan External yang dalam hal ini adalah masyarakat dilingkungan Rumah Sakit yang membenarkan tentang pernyataan tersebut, setelah semuanya penulis ceritakan informan mengemukakan bahwa :

Keterlibatan atau interaksi antara RSUD Dr. H. Moh. Anwar Sumenep dengan masyarakat sangat baik karena rumah sakit selalu peduli pada kesehatan masyarakat terbukti dengan adanya sosialisasi tentang bahaya penyakit pada masyarakat serta sunatan massal yang dilakukan RS tiap tahun sangat membantu bagi masyarakat yang kurang mampu, serta adanya peningkatan kualitas pelayanan.

Sedangkan Rumah Sakit Islam

Garam Kalianget yang mengatakan bahwa kegiatan Corporate Social Responsibility yang sudah terlaksana tidak jauh berbeda dengan RSUD akan tetapi langsung di tangani oleh bagian Humas

Kegiatan Corporate Social Responsibility yang dilakukan Rumah Sakit Islam Garam Kalianget saat ini berupa:

1. Pengolahan limbah yang peduli pada lingkungan. 


\section{FAKULTAS EKONOMI DAN BISNIS UNIVERSITAS WIRARAJA - MADURA}

2. Kerja sama dengan beberapa perguruan tinggi.

3. Perlindungan kesehatan bagi karyawan dan pelanggan.

4. Peningkatan SDM karyawan.

5. Bantuan bencana kemanusiaan.

6. Pengembangan skema perlindungan sosial berbasis masyarakat.

7. Interaksi atau keterlibatan Rumah Sakit dengan masyarakat.

Hal tersebut diatas terungkap dari wawancara dengan informan Kunci (Ibu Tia) Pada tanggal 22 November 2016 dan dikompermasi dengan bagian Humas Pada tanggal 23 November 2016 yang menyatakan bahwa :

Memang benar kegiatan Corporate Social Responsibility yang dilakukan Rumah Sakit Islam Garam Kalianget saat ini sudah terlaksanadan disesuaikan dengan kebutuhan masyarakat setempat berdasarkan kebutuhan, Yang rata-rata pengelolaannya melalui bidang Humas.

Lebih lanjut diungkapkan oleh informan External yang dalam hal ini adalah masyarakat dilingkungan Rumah Sakit Islam Garam Kalianget yang membenarkan tentang pernyataan tersebut, setelah semuanya penulis ceritakan informan mengemukakan bahwa :

Keterlibatan atau interaksi antara Rumah Sakit Islam Garam Kalianget dengan masyarakat sangat baik karena rumah sakit selalu peduli pada kesehatan masyarakat terbukti dengan adanya sosialisasi tentang bahaya penyakit pada masyarakat serta sunatan massal yang dilakukan tiap tahun sangat membantu bagi masyarakat yang kurang mampu, dan adanya peningkatan kualitas pelayanan serta fasilitas umum yang ada dalam rumah sakit.

Dari beberapa program

Corporate Social Responsibility yang telah dilakukan oleh Dua Rumah Sakit diatas sudah mencerminkan bahwa sudah terlaksananya Corporate Social Responsibility pada Rumah Sakit tersebut, dimana program Corporate Social Responsibility sebagai sebuah gagasan yang bagus untuk pembangunan yang berkelanjutan, Rumah Sakit tidak lagi dihadapkan pada tanggungjawab yang berpijak pada single bottom line yaitu nilai perusahaan (corporate value) yang direfleksikan dalam kondisi keuangannya (financial saja) tetapi harus berpijak pada triple bottom lines, dimana bottom lines selain financial juga adalah sosial dan lingkungan.

Karena kondisi keuangan saja tidak cukup menjamin nilai organisasi atau unit kerja untuk tumbuh secara berkelanjutan (sustainable).

Berdasarkan standar dari Bank Dunia tentang pertanggungjawaban social Perusahaan (Corporate Social Responsibility) meliputi beberapa komponen utama yakni:

1) Perlindungan lingkungan

2) Jaminan kerja

3) Hak Asasi Manusia

4) Interaksi dan keterlibatan perusahaan dengan masyarakat

5) Standar usaha

6) Pasar 
7) Pengembangan ekonomi dan badan usaha

8) Perlindungan kesehatan

9) Kepemimpinan dan pendidikan

10) Bantuan bencana kemanusiaan.

Dari hasil evaluasi dan data yang ada maka dapat disimpulkan bahwa kedua Rumah Sakit yang ada di Wilayah Kabupaten Sumenep belum bisa dikatakan $100 \%$ melaksanakan standar pelaksanaan Corporate Social Responsibility dari segi teori pelaksanaan Corporate Social Responsibility sesuai standar dari Bank dunia dengan dasar tanggung jawab yang berdasar pada teori single bottom line. Hal ini dikarenakan kedua Rumah Sakit yang ada di Wilayah Kabupaten Sumenep belum sepenuhnya melakukan beberapa kategori dari standar yang ditetapkan Bank dunia atau tidak adanya Bidang yang khusus menangani Corporate Social Responsibility .

Rumah Sakit yang ada di Wilayah Kabupaten Sumenep sebagai perusahaan publik, selain mempunyai tugas dan tanggung jawab bisnis untuk menyediakan pelayanan kesehatan bagi masyarakat, juga mempunyai tanggung jawab sosial perusahaan atau Corporate Social Responsibility kepada masyarakat umum untuk membantu pemberdayaan masyarakat di berbagai bidang, seperti bidang ekonomi, sosial, pendidikan, lingkungan, keagamaan, dan lain-lain.
Dalam teori Piramida tentang Corporate Social Responsibility dapat dilihat berdasarkan empat jenjang yang merupakan satu kesatuan. Jika menurut teori Piramida Rumah Sakit di Wilayah Kabupaten Sumenep bisa dikatakan telah melakukan kegiatan Corporate Social Responsibility dengan baik karena semua Tanggung Jawab Rumah Sakit secara umum telah terpenuhi:

1. Tanggung Jawab Filantropis Rumah Sakit ini mempunyai kelas C, dan merupakan Rumah Sakit rujukan utama bagi sarana pelayanan kesehatan pemerintah dan swasta yang ada di wilayah Kabupaten Sumenep, baik di daratan maupun kepulauan yang ada di Kabupaten Sumenep.

2. Tanggung Jawab Legal

Rumah Sakit yang ada di Wilayah Kabupaten Sumenep sudah berbadan hukum (RSUD. Dr. H. Moh. Anwar Sumenep. Dan Rumah Sakit Islam Garam Kalianget)

\section{Tanggung Jawab Etika}

Tanggung jawab etika yang dilakukan oleh Rumah Sakit yang ada di Wilayah Sumenep telah cukup terlaksana dengan baik. Dari segi pelayanan dan juga hubungan dengan masyarakat dalam hal ini pelaksanaan Corporate Social Responsibility Rumah Sakit keduanya dikatakan telah memenuhi 
teori piramida tentang standar pelaksanaan Corporate Social Responsibility.

4. Tanggung Jawab Ekonomi

Dalam tanggung jawab ekonomi ini Rumah Sakit yang Ada Di Wilayah Sumenep telah jelas dapat dikatakan telah memenuhi syarat. Karena dalam tanggung jawab ekonomi ini Rumah Sakit di Sumenep tidak hanya melakukan pelayanan kepada masyarakat tapi juga profit untuk membiayai kegiatan operasionalnya.

Corporate Social Responsibility tidak memberikan hasil secara keuangan dalam jangka pendek. Namun Corporate Social Responsibility akan memberikan hasil baik langsung maupun tidak langsung pada keuangan organisasi atau unit kerja di masa mendatang. Investor juga ingin investasinya dan kepercayaan masyarakat terhadap organisasi atau unit kerja memiliki citra yang baik di mata masyarakat umum. Dalam proses perjalanan Corporate Social Responsibility Rumah Sakit di Wilayah Sumenep banyak masalah yang dihadapinya, di antaranya adalah :
1. Program Corporate Social Responsibility belum tersosialisasikan dengan baik di masyarakat.

2. Belum adanya aturan yang jelas dalam pelaksanaan Corporate Social Responsibility di Rumah Sakit.
3. Belum adanya Bidang yang Secara khusus menangani CSR (Corporate Social Responsibility)

Bila dianalisis permasalahan di atas program Corporate Social Responsibility yang dilakukan Rumah Sakit Sumenep belum tersosialisasai di kalangan masyarakat. Hal ini menyebabkan program Corporate Social Responsibility belum bergulir sebagai mana mestinya, mengingat masyarakat umum belum mengerti apa itu program Corporate Social Responsibility. Apa saja yang dapat dilakukannya? Bagaimana dapat berkolaborasi dengan prosedur organisasi atau unit kerja. Untuk menjawab pertanyaan masyarakat umum, perlu dijelaskan keberhasilan program Corporate Social Responsibility baik di media cetak, atau media elektronika dan memberikan contoh keberhasilan program Corporate Social Responsibility yang telah dijalankan.

Corporate Social Responsibility organisasi atau unit kerja menimbulkan penafsiran sendiri, hal ini dapat dilihat dari masing-masing organisasi atau unit kerja yang memiliki program Corporate Social Responsibility. Perlu diketahui program Corporate Social Responsibility yang terpenting adalah aturan yang mewajibkan programnya harus berkelanjutan (sustainable). 
Melakukan program Corporate Social Responsibility yang berkelanjutan akan memberikan dampak positif dan manfaat yang lebih besar baik kepada perusahaan itu sendiri berupa citra perusahaan dan para stake holder yang terkait.

Peranan Akuntan Intern Dalam Pelaksanaan Corporate Social Responsibility Rumah Sakit di Wilayah Kabupaten Sumenep

$$
\text { Perlunya pengembangan }
$$

Pertanggungjawaban sosial perusahaan (Corporate Social Responsibility) yang relevan untuk dapat menciptakan suatu kondisi stabilitas sosial dari lingkungan sosial suatu entitas bisnis, sehingga diperlukan kepedulian dan kepekaan suatu entitas bisnis terhadap permasalahan sosial yang turut mendukung terciptanya tanggungjawab sosial perusahaan. Dengan demikian pengungkapan sosial pada laporan tahunan perusahaan hendaknya bukanlah merupakan pengungkapan secara sukarela (Voluntary Disclosure) tetapi dapat dipikirkan menjadi suatu keharusan (Mandatory Disclosure). Disinilah peran organisasi dan profesi akuntan dituntut untuk merespon perkembangan lingkungan dunia bisnis di Indonesia yang senantiasa berubah sangat cepat.

Dalam wawancara dengan para akuntan intern Rumah Sakit di Wilayah Kabupaten Sumenep.
Kami bertugas melakukan fungsi penilaian bagi perusahaan, untuk memeriksa dan mengevaluasi kegiatan-kegiatan perusahaan (baik bersifat Sosial atau non Sosial) dengan menekankan pada tujuan membantu manajemen untuk melaksanakan tugasnya dengan baik dan agar tanggungjawab tersebut dapat dilaksanakan secara efektif serta menyajikan analisis-analisis, penilaian-penilaian, saran-saran, bimbingan-bimbingan, dan informasi yang berhubungan dengan kegiatankegiatan yang telah ditelaah, dipelajari, dan dinilainya.

Hal ini terungkap dan di jelaskan secara detail oleh informan Kunci (Akuntan Intern) yang ada di Rumah Sakit RSUD Kabupaten Sumenep pada Tanggal 29 November 2016 dan jawaban yang tidak jauh berbeda dengannya. Informan Kunci (Akuntan Intern) Rumah Sakit Islam Garam Kalianget benambahkan bahwa :

Kami juga menyajikan analisisanalisis, penilaian-penilaian Kegiatan Pertanggungjawaban sosial perusahaan (Corporate Social Responsibility) serta saran-saran, dan bimbingan-bimbingan, serta informasi yang berhubungan dengan kegiatan-kegiatan yang telah ditelaah, dipelajari, dan dinilainya.

Setelah dikomfirmasi pada tanggal 30 November 2016 dengan bagian keuangan dan humas akuntan intern menyarankan dan memberi penilaian terhadap kegiatan Pertanggungjawaban sosial perusahaan (Corporate Social Responsibility) yang dilakukan oleh Perusahaan bagaimana kegiatan tersebut harus terus dilakukan 
secara berkelanjutan sehingga

memberikan dampak positif dan manfaat yang lebih besar baik kepada perusahaan itu sendiri yaitu berupa citra perusahaan dan para stake holder yang terkait serta kepada masyarakat sekitarnya.

Harapan masyarakat terhadap akuntan berkembang dari hanya kebutuhan informasi aspek keuangan perusahaan, melebar pada aspek lingkungan sosial. Akuntan Intern diharapkan tidak hanya bisa menunjukkan tingkat kesehatan perusahaan dan prediksinya dimasa depan. Namun juga harus bisa memberikan gambaran tentang kepedulian terhadap lingkungan sosial dengan pertanggung jawabab sosial perusahaan yang dituangkan dalam kegiatan social kemasyarakatan.

Hal ini mengindikasikan bahwa internal auditing yaitu internal auditor, harus dinamis dan mempunyai orientasi atau pandangan sekarang dan masa yang akan datang. Karena ia berkedudukan sebagai penilai (Appraisal) yang independen, maka internal auditor harus betul-betul bebas, baik dalam sikap maupun penilaian-penilaiannya. Disamping itu ia harus mampu dan tanggap akan ukuran-ukuran (Measures) yang akan digunakan dalam penilaiannya. Keberhasilan dan tingkat efisiensi suatu kegiatan harus didasarkan pada perbandingan atas ukuran-ukuran dan prestasi. Ukuran yang digunakan tidak hanya terdiri dari budget, standar biaya, dan standar kualitas, tetapi atas dasar pertimbangan-pertimbangan bebas, maka dapat digunakan ukuranukuran lain yang mungkin dapat digunakan.

Internal Auditor bertugas melakukan fungsi penilaian bagi perusahaan, untuk memeriksa dan mengevaluasi kegiatan-kegiatan perusahaan dengan menekankan pada tujuan membantu manajemen untuk melaksanakan tugasnya dengan baik disamping itu akuntan intern mempunyai tanggung jawab untuk melaporkan semua temuan-temuan yang diperoleh dalam melaksanakan tugasnya kepada direktur selaku pimpinan perusahaan atau Rumah Sakit.

Kegiatan internal auditing bertujuan untuk membantu semua tingkatan manajemen agar tanggungjawab tersebut dapat dilaksanakan secara efektif. Internal auditing menyajikan analisis-analisis, penilaian-penilaian, saran-saran, bimbingan-bimbingan, dan informasi yang berhubungan dengan kegiatankegiatan Pertanggungjawaban sosial perusahaan (Corporate Social Responsibility) yang telah ditelaah, dipelajari, dan dinilainya. Sehingga akuntan intern mempunyai kesimpulan yang harus dilaporkan kapada direktur 
untuk jadi bahan pertimbangan dalam menentukan kebijakan kegiatan sosial selanjutnya.

Peranan akuntan intern dalam pelaksanaan kegiatan - kegiatan sosial sangat dibutuhkan untuk pertanggung jawaban sosial perusahaan (Rumah Sakit di Wilayah Kabupaten Sumenep). Karena keterlibatan akuntan intern sangat besar pengaruhnya tehadap proses pengambilan keputusan yang terkait dengan masalah-masalah social atau Pertanggungjawaban sosial perusahaan (Corporate Social Responsibility)

\section{Simpulan}

Internal Auditor adalah Akuntan intern yang bertugas melakukan analisis dan penilaian secara sistematis dan objektif tentang operasi dan pengendalian kegiatan-kegiatan perusahaan. Audit internal yang dilakukan internal auditor merupakan fungsi penilaian independen. Peran akuntan intern dalam pelaksanaan Pertanggungjawaban sosial perusahaan (Corporate Social Responsibility) di Rumah Sakit di Wilayah Kabupaten Sumenep sangatlah dibutuhkan untuk mendorong perusahaan melaksanakan pertanggung jawaban sosial dimana dengan tanggung jawab sosial perusahaan tersebut akan dapat menciptakan suatu kondisi stabilitas sosial dari lingkungan sosial suatu entitas bisnis.

Pertanggung jawaban sosial perusahaan dalam hal ini Rumah Sakit di Wilayah Kabupaten Sumenep belum memiliki standar yang jelas, sehingga pelaksanaan pertanggung jawaban sosial Rumah Sakit hanya bergantung pada kerelaan pihak organisasi, dan bukan merupakan kewajiban untuk mengungkapkan pada laporan keuangan Rumah Sakit.

\section{Saran}

1. Seharusnya dunia usaha atau pelaku bisnis baik yang profit oriented maupun non profit oriented lebih bersifat proaktif agar dapat menjaga keharmonisan hubungan antara perusahaan dengan lingkungan sekitarnya, sehingga dampak jangka panjang khusunya untuk kelangsungan hidup perusahaan terjamin.

2. Kegiatan Pertanggungjawaban sosial perusahaan (Corporate Social Responsibility) Rumah Sakit di Wilayah Kabupaten Sumenep harus terus diusahakan secara Maksimal dan berkelanjutan.

3. Perlu adanya suatu tekanan dan rangsangan dari pemerintah, baik dalam bentuk program, kebijakan, peraturan maupun Awards atau penghargaan lingkungan sosial, sehingga dunia usaha lebih 
meningkatkan kesadaran dan

kepedulian terhadap lingkungan.

\section{DAFTAR PUSTAKA}

Adam, Carol, A, et.al., 1997, Corporate Social Reporting Practices in Western Europe: Legitimating Corporate behavior, Working Paper, Departement of accounting and Finance, University of Glasglow, England.

Andrew, BH. FA. Gaul, et.al., 1989, A Note of Corporate Social Disclosure Practise in Developing Cotries: The Cases of malaysia and Singapure, British Accounting Review, Vol.21 pp.371-376.

Astuti, 1998, Analisa Pengaruh Akuntan Intern Terhadap Evaluasi Perusahaan Pada Masalah Sosial, Skrip tidak diterbitkan, Fakultas Ekonomi Universitas Gajayana Malang.

Belkaoui, Ahmed Riahi, 2000, Teori Akuntansi, Buku I. Terjemahan Sarwata dkk, Jakarta. Salemba Empat.

Harahap, Sofyan Syafri, 1988, Sosio Economic Accounting (SEA) : Menyoroti Etika dan Tanggungjawab Sosial Perusahaan, Majalah Akuntansi No. 3 Bulan Maret.

Hartadi, Bambang, 1991, Internal Auditing: Suatu TinjauanSistem Informasi Manajemen dan Cara Pelaporannya, Andi Offset, Yogyakarta.

Henny dan Murtanto, 2001 Analisis Pengungkapan Sosial Pada Laporan Tahunan, Media Riset Akuntansi, Auditing dan Informasi, Universitas Trisakti, Jakarta.

Hendriksen, Eldon, S, 1994, Accounting Theory, Third Edition, Mc. Hill, USA.
Hendriksen, Eldon, S. Dan Van Breda, Michael F., 2000, Accounting Theory, edisi ke lima, Terjemahan hermawan Wibowo dan Editor Lindon Saputra, Interaksara, Batam.

Ikatan Akuntan Indonesia, 1999, Standar Akuntansi Keuangan, Jakarta: Salemba Empat.

ISO 26000 Tahun 2010 tentang standar internasional CSR.

Nurdizal M. Rachman, Asep Efendi, Emir Wicaksana, "Panduan Lengkap Perencanaan CSR". Penebar Swadaya. Cetakan 1. Jakarta. 2011.

Rahmatullah dan Trianita Kurniawati, "Panduan Praktis Pengelolaan CSR". Samudra Biru. Cetakan 1. Yogyakarta. Juli 011.

Syahril 2012, Peranan Akuntan Dalam Pelaksanaan Akuntansi Sosial di Perusahaan" Proseding Universitas Wiraraja Sumenep

Suharto, Edi. 2008. Corporate Social Responsibility. Alfabeta: Bandung

Sugiyono. 2008. Metode Penelitian Kuantitatif Kualitatif dan R\&D. Alfabeta : Bandung

Sukardi, David. 2009. Manajemen Strategi. Graha Ilmu: Yogyakarta

Wibisono, Yusuf. 2004. Analisis Sosioligis Terhadap Implementasi CSR Pada Masyarakat Indonesia. PT Bumi Aksara; Jakarta

Undang-Undang No. 40 Tahun 2007 tentang Perseroan Terbatas.

Undang-Undang No. 25 Tahun 2007 tentang Penanaman Modal.

Undang-Undang No. 20 Tahun 2008 tentang Usaha Mikro, Kecil dan Menegah. 